\title{
FORMULASI SEDIAAN SHAMPOO CAIR EKSTRAK ETANOL DAUN ALAMANDA (Allamanda cathartica L.) DENGAN CARBOPOL 940 SEBAGAI PENGENTAL
}

\section{FORMULATION LIQUID SHAMPOO EXTRACT ETHANOL OF ALAMANDA LEAF (Allamanda cathartica L.) WITH CARBOPOL 940 AS THICKNER}

\author{
Dian Kartikasari ${ }^{1}$, Dina Yuspitasari ${ }^{1}$, Lindasari $^{1}$ \\ ${ }^{1}$ Akademi Farmasi Yarsi Pontianak \\ Jl. Panglima A'im no. 2 Pontianak \\ Email: diankartikasari223@gmail.com
}

\begin{abstract}
ABSTRAK
Telah dilakukan penelitian formulasi sediaan shampoo cair ekstrak etanol daun alamanda (Allamanda cathartica L.) dengan carbopol 940 sebagai pengental. Penelitian ini bertujuan untuk membuat formulasi dan menentukan konsentrasi carbopol 940 sebagai pengental yang dapat menghasilkan sediaan shampoo yang baik. Penelitian menggunakan 3 formula shampoo, dengan variasi konsentrasi carbopol 1\%, 1,5\%, dan 2\%. Evaluasi yang dilakukan meliputi uji organoleptis, $\mathrm{pH}$, ketahan busa, bobot jenis, dan viskositas. Hasil dari evaluasi organpleptis didapatkan shampoo ekstrak etanol daun alamanda berbau khas alamanda, berwarna hijau dan berbentuk cair. Hasil pengukuran $\mathrm{pH}$ didapatkan formula I dan II 4,2 dan formula III 6,8. Pada pengukuran tinggi busa didapatkan formula I tinggi busanya 6,1 $\mathrm{cm}$, formula II tinggi busanya $4,5 \mathrm{~cm}$, dan formula III tinggi busanya $4 \mathrm{~cm}$. pengukuran bobot jenis didapatkan formula I dan II adalah 1,03 dan formula III adalah 1 . Pada pengukuran viskositas didapatkan s formula I $0,43 \mathrm{dPa}$ 's, formula II $0,96 \mathrm{dPa}$ 's, dan formula III $1,5 \mathrm{dPa}$ 's.
\end{abstract}

Kata kunci : carbopol 940, Ekstrak etanol daun alamanda, shampoo cair.

\begin{abstract}
A study about ethanol extract of alamanda leaves (Allamanda cathartica L.) liquid shampoo formulation with carbopol 940 as a thickener agent has been accomplised. This study was carried out to formulations and determine the concentration of carpobol 940 that can produce a good formula of shampoo. The study used three shampoo formula, with variations Carbopol concentration of $1 \%, 1.5 \%$ and $2 \%$. Evaluation was conducted on the organoleptic test, $\mathrm{pH}$, foam resilience, specific gravity and viscosity. The results of the evaluation obtained organpleptis shampoo ethanol extract of leaves alamanda distinctive smell Alamanda, green and liquid form. PH measurement results obtained formula I and II, 4.2 and III 6.8 formula. At the height measurement formula I obtained foam height of $6.1 \mathrm{~cm}$ foam, foam formula II high of $4.5 \mathrm{~cm}$, and high-foam formula III $4 \mathrm{~cm}$. measuring the specific gravity of formula I and II obtained was 1.03 and the formula III is 1 . In viscosity measurements obtained s formula I DPA's $0.43,0.96$ DPA's formula II, and formula III 1.5 DPA's.
\end{abstract}

Keywords : carbopol 940, ethanol extract of leaves alamanda, liquid shampoo. 


\section{PENDAHAULUAN}

Penyakit kulit pada kepala seringkali muncul karena kondisi kulit yang mudah berkeringat dan lembab. Kebersihan diri yang tidak terjaga dan kurangnya pengetahuan tentang kesehatan merupakan faktor yang memungkinkan pertumbuhan jamur penyebab penyakit kulit (Arundhina, E., 2014). Salah satu penyakit kulit pada kepala yang sering dikeluhkan masyarakat adalah ketombe. Shampoo merupakan sediaan kosmetik yang paling luas dimanfaatkan untuk mengatasi masalah tersebut.)

Shampoo adalah sediaan kosmetik berwujud cair, gel, emulsi, ataupun aerosol ataupun yang mengandung surfaktan, sehingga memiliki sifat detergensi,humektan dan menghasilkan busa. Shampoo merupakan sediaan kosmetika yang digunakan untuk membersihkan rambut, sehingga rambut dan kulit kepala menjadi bersih dan sedapat mungkin lembut, mudah diatur dan berkilau (Faizatun, dkk, 2008).

Fungsi shampoo adalah untuk menghilangkan lemak (seperti sebun) dan pembalut rambut yang mengikat partikel kotoran kerambutnya. Formula yang terkadung dalam bagian shampoo ini bervariasi mulai dari cair, lotion, krim, dan pasta,dengan beberapa bahan khusus yang mengandung telur, protein, warna dan bahan anti ketombe (Michael \& Ash, 1977).

Allamanda cathartica L. digunakan sebagai zat aktif dalam formula karena diprediksi memiliki senyawa aktif sebagai antijamur Pityrosporum Oval (jamur penyebab ketombe) dan berdasarkan uji KBM (Konsentrasi Bunuh Minimum) yang telah dilakukan oleh Arundhina didapat konsentrasi 10\% dianggap konsentrasi yang paling baik (Arundhina, E., 2014).

Allamanda cathartica L. mengandung senyawa fitokimia, antara lain alkaloid,flavonoid, terpenoid, steroid, saponin dan tanin. Terpenoid yang termasuk triterpenoid dan steroid merupakan senyawa bioaktif yang memiliki fungsi sebagai anti jamur, senyawa tersebut dapat menghambat pertumbuhan jamur, baik melalui membran sitoplasma maupun mengganggu pertumbuhan dan perkembangan spora jamur. KHM (Konsentrasi Hambat Minimal) dari ekstrak etanol daun alamanda terhadap jamur Pityrosporum Ovale adalah 9\% sedangkan untuk konsentrasi KBM (Konsentrasi Bunuh Minimal) pada ekstrak etanol daun alamanda adalah $10 \%$, jadi alasan pemilihan konsentrasi $10 \%$ di dalam formulasi ini karena pada konsentrasi $10 \%$ dapat membunuh jamur (Arundhina, E., 2014).

Carbopol merupakan suatu polimer dan biasa digunakan sebagai bahan pengental. Jenis Carbopol yang memiliki viskositas dan kejernihan paling baik adalah Carbopol 940. Maka dengan dibuat beberapa sediaan shampoo menggunakan bahan pengental Carbopol 940 yang konsentrasinya dibuat bertingkat dan kemudian dievaluasi, dapat diketahui bagaimana konsentrasi carbopol 940 berpengaruh terhadap viskositas dan ketahanan busa (Felicyta, 2010). Untuk itu peneliti tertarik untuk membuat formula shampoo anti ketombe dari daun alamanda yang dapat menghambat dan membunuh jamur penyebab ketombe yaitu Pityrosporum Oval.

\section{METODE PENELITIAN}

\section{Alat dan Bahan}

Alat yang digunakan dalam penelitian ini antara lain, mortir dan stamper, batang pengaduk, gelas ukur, beaker glass, neraca analitik, kaca arloji, sendok stainless dan sendok tanduk, viscotester VT-04E, pH meter, rotary evaporator. Bahan yang digunakan adalah Ekstrak Etanol Daun Alamanda, Sodiumlauril Sulfat, Carbopol 940, Propilenglikol, Propil Paraben, Metil Paraben, Edetic Acid, dan aquadest.

\section{Jalannya Penelitian}

Jalannya penelitian terdiri atas empat tahap, yaitu:

1. Pembuatan Simplisia Daun Alamanda 
Daun yang masih segar dicuci bersih dan dikering anginkan, setelah itu dipotong kecilkecil atau dirajang. Proses pengeringan daun alamanda menggunakan sinar matahari dengan ditutup kain berwarna hitam.

2. Ekstraksi

Maserasi dengan etanol 96\%. Maserasi dilakukan dalam wadah bewarna gelap, selama 3 x 24 jam dengan perbandingan (pelarut etanol : simplisia daun alamanda) 1:5, 1:3, dan 1:2, kemudian ekstrak disaring dengan menggunakan kain flanel. Ekstrak tersebut kemudian dipekatkan dengan rotary evaporator pada suhu $40^{\circ} \mathrm{C}$ sehingga didapatkan ekstrak pekat.

3. Pembuatan Sediaan Sampo

Kembangkan Carbopol 940 dengan cara ditaburkan diatas air panas hingga mengembang. sampai kembang kemudian tambahkan metil paraben dan sodium lauril sulfat yang telah dilarutkan dalam air dan diaduk hingga homogen (bagian 1). Propil paraben dilarutkan dengan propilenglikol kemudian ditambahkan dengan EDTA dan diaduk hingga homogen (bagian 2). Bagian 1 dimasukan kedalam bagian 2 sedikit demi sedikit diaduk hingga homogen setelah itu ditambahkan ekstrak kental etanol daun alamanda, selanjutnya sisa aquadest dimasukan kedalam campuran bahan tersebut dan diaduk sampai homogen.

Tabel I. Formula Shampoo Cair Setiap $70 \mathrm{ml}$

\begin{tabular}{cccc}
\hline \multirow{2}{*}{ Bahan } & \multicolumn{3}{c}{ Konsentrasi (\%) } \\
\cline { 2 - 4 } & I & II & III \\
\hline Ekstrak daun allamanda & 10 & 10 & 10 \\
Carbopol 940 & 1 & 1,5 & 2 \\
Sodium Lauril Sulfat & 10 & 10 & 10 \\
Propilenglikol & 5 & 5 & 5 \\
Propil Paraben & 0,02 & 0,02 & 0,02 \\
Metil Paraben & 0,18 & 0,18 & 0,18 \\
Edetic Acid & 0,1 & 0,1 & 0,1 \\
Aquadest & $\mathrm{ad} \mathrm{100}$ & $\mathrm{ad} 100$ & $\mathrm{ad} \mathrm{100}$ \\
\hline
\end{tabular}

4. Evaluasi Sediaan

Sediaan shampoo yang dibuat dengan berbagai konsentrasi kemudian di evaluasi. Terdapat lima metode evaluasi yang dilakukan yaitu:

1. Organoleptis

Pengamatan dilakukan pada setiap perubahan meliputi tekstur, bau, dan warna sediaan shampoo cair ekstrak daun alamanda yang dilakukan oleh tiga orang sukarelawan.

2. Pengukuran $\mathrm{pH}$

Pengukuran $\mathrm{pH}$ sediaan shampoo cair menggunakan alat $\mathrm{pH}$ meter. Alat terlebih dahulu dikalibrasi, setelah itu $\mathrm{pH}$ meter dicelupkan kedalam larutan sediaan shampoo cair (sediaan shampoo terlebih dahulu diencerkan dengan air perbandingan 1:10), dibiarkan alat menunjukan angka $\mathrm{pH}$ sampai konstan. Angka yang ditunjukkan $\mathrm{pH}$ meter merupakan $\mathrm{pH}$ sediaan. 
3. Viskositas

Penentuan viskositas dilakukan dengan menggunakan Viscotester VT-04E. Sediaan shampoo cair dimasukkan dalam wadah yang dipasang pada viscotester. Viskositas shampoo cair diketahui dengan mengamati jarum penunjuk pada viscotester.

4. Bobot Jenis

Pengukuran bobot jenis menggunakan piknometer. Rumus perhitungan:

$$
\mathrm{BJ}=\frac{C-A}{B-A}
$$

$$
\text { keterangan: } \begin{aligned}
A & =\text { Pikno Kosong } \\
B & =\text { Pikno berisi air } \\
C & =\text { Pikno berisi larutan formula }
\end{aligned}
$$

(Faizatun, 2008).

5. Tinggi Busa

Sediaan shampoo ekstrak etanol daun alamanda dicampurkan dengan sedikit air suling kedalam gelas ukur tertutup. Campuran tersebut dikocok selama 20 detik dengan cara membalikan gelas ukur secara beraturan. Tinggi busa yang terbentuk diamati (tinggi busa awal) dan 5 menit kemudian diamati kembali (tinggi busa akhir).

Rumus stabilitas busa:

Stabilitas busa $=100 \%-(\%$ busa yang hilang $)$

Rumus \% busa yang hilang:

$$
\text { Busa yang hilang }=\frac{\text { tinggi busa awal }- \text { tinggi busa akhir }}{\text { tinggi busa awal }} \times 100 \%
$$

\section{HASIL DAN PEMBAHASAN}

Berdasarkan hasil pengamatan organoleptis yang telah dilakukan pada tiap formula dengan tiga kali replikasi, didapatkan hasil sediaan shampoo cair yang berbau khas alamanda, berwarna hijau dan pada formula I dan II berbentuk cair kemudian formula III berbentuk kental. Penambahan ekstrak etanol daun alamanda juga menyebabkan adanya bau khas alamanda pada sediaan shampoo cair. Konsistensi dan intensitas warna tidak berubah

\begin{tabular}{|c|c|c|c|c|c|}
\hline \multirow{2}{*}{ No } & \multirow{2}{*}{ Formula } & \multirow{2}{*}{ Replikasi } & \multicolumn{3}{|c|}{ Organoleptis } \\
\hline & & & Bau & Warna & Bentuk \\
\hline \multirow[t]{3}{*}{1} & I & I & Khas Alamanda & Hijau & Cair \\
\hline & & II & Khas Alamanda & Hijau & Cair \\
\hline & & III & Khas Alamanda & Hijau & Cair \\
\hline \multirow[t]{3}{*}{2} & II & I & Khas Alamanda & Hijau & Cair \\
\hline & & II & Khas Alamanda & Hijau & Cair \\
\hline & & III & Khas Alamanda & Hijau & Cair \\
\hline \multirow[t]{3}{*}{3} & III & I & Khas Alamanda & Hijau & Cair \\
\hline & & II & Khas Alamanda & Hijau & Cair \\
\hline & & III & Khas Alamanda & Hijau & Cair \\
\hline
\end{tabular}
dengan adanya bahan tambahan dan peningkatan konsentrasi basis carbopol. hal ini dapat dilihat pada tabel II.

Tabel II. Hasil evaluasi organoleptis pada sedian sampo cair ekstrak etanol daun alamanda 
pH shampoo harus disesuaikan dengan pH rambut dan kulit kepala, yaitu sekitar (56). $\mathrm{pH}$ shampoo yang terlalu asam akan merusak ikatan hidrogen dan jembatan garam pada struktur rambut. Sebaliknya $\mathrm{pH}$ lebih dari 8,5 akan merusak ikatan disulfide, dan $\mathrm{pH}$ lebih dari 12 akan merusak ikatan hydrogen dan jembatan garam pula. Bila ketiga ikatan tersebut hilang maka rambut akan menjadi kasar dan kemudian rusak (Corcoran, 1997). Hasil pengukuran $\mathrm{pH}$ sediaan shampoo cair berdasarkan tabel III, didapatkan $\mathrm{pH}$ pada formula I dan formula II yaitu 4,2 dan formula III didapat pH yaitu 6,8.

Tabel III. Hasil evaluasi pengukuran pH sediaan shampoo cair ekstrak etanol daun alamanda

\begin{tabular}{ccccc}
\hline \multirow{2}{*}{ Formula } & \multicolumn{3}{c}{$\mathrm{pH}$} & \multirow{2}{*}{ Rata-rata $\mathrm{pH}$} \\
\cline { 2 - 4 } & Replikasi I & Replikasi II & Replikasi III & \\
\hline I & 4,2 & 4,2 & 4,2 & 4,2 \\
II & 4,2 & 4,2 & 4,2 & 4,2 \\
III & 6,8 & 6,8 & 6,8 & 6,8 \\
\hline
\end{tabular}

Berdasarkan pada tabel diatas diketahui pada formula I dan II sediaan shampoo bersifat lebih asam dibandingkan formula III. seperti yang diketahui bahwa pada formula shampoo ini tidak ada penambahan agen pengatur $\mathrm{pH}$ sehingga $\mathrm{pH}$ yang dihasilkan dipengaruhi oleh komponen didalam sediaan shampoo, komponen yang bersifat asam diantaranya surfaktan SLS yang merupakan ester organik dari asam sulfat (Barel, 2009), dan EDTA sebagai asam lemah. Peningkatan $\mathrm{pH}$ juga dapat disebabkan oleh gugus karboksilat pada carbopol yang terionisasi didalam air (bereaksi dengan mineral yang terkandung didalam air) menjadi bermuatan negatif s dan akan terjadi saling tolak - menolak antar sesamanya(Allen, 2002).

Tabel IV. Hasil evaluasi pengukuran tinggi busa sediaan shampoo cair ekstrak etanol daun alamanda

\begin{tabular}{ccccc}
\hline \multirow{2}{*}{ Formula } & \multicolumn{3}{c}{ Tinggi busa $(\mathrm{cm})$} & \multirow{2}{*}{ Rata-rata } \\
\cline { 2 - 4 } & Replikasi I & Replikasi II & Replikasi III & $(\mathrm{cm})$ \\
\hline I & 5,6 & 6,8 & 6 & 6,1 \\
II & 4,5 & 4,5 & 4,5 & 4,5 \\
III & 4 & 4 & 4 & 4 \\
\hline
\end{tabular}

Hasil pengukuran tinggi busa mencerminkan kemampuan suatu deterjen untuk menghasilkan busa. Pengukuran tinggi busa merupakan salah satu cara untuk pengendalian mutu suatu produk deterjen agar sediaan memiliki kemampuan yang sesuai dalam dalam menghasilkan busa. Tidak ada syarat untuk tinggi busa minimum maupun maksimum untuk suatu sediaan shampoo, karena tinggi busa tidak menunjukkan kemampuan dalam membersihkan. Hal ini lebih dihubungakan kepada nilai estetika dan kesukaan konsumen yang menyukai timbulnya busa berlebih. Berdasarkan hasil pengamatan tinggi busa pada tabel IV, didapat bahwa pada formula I didapatkan busa setinggi $6,1 \mathrm{~cm}$, pada formula II didapat tinggi busa $4,5 \mathrm{~cm}$, dan pada formula III didapat tinggi busa $4 \mathrm{~cm}$. terbentuknya busa dipengaruhi oleh surfaktan yang digunakan, kesadahan air, suhu ruang saat pengukuran, waktu pendiaman, dan pengental (carbopol 940) dalam formula shampoo yang juga berfungsi sebagai penstabil busa (DepKes RI, 1985). 
Tabel V. Hasil evaluasi pengukuran bobot jenis sediaan shampoo cair ekstrak etanol daun alamanda

\begin{tabular}{ccccc}
\hline \multirow{2}{*}{ Formula } & \multicolumn{3}{c}{ Bobot Jenis } & \multirow{2}{*}{$\begin{array}{c}\text { Rata-rata } \\
\text { bobot jenis }\end{array}$} \\
\cline { 2 - 4 } & Replikasi I & Replikasi II & Replikasi III & 1,03 \\
I & 1,03 & 1,03 & 1,03 & 1,03 \\
II & 1,03 & 1,03 & 1,03 & 1,0 \\
III & 1,0 & 1,0 & 1,0 & \\
\hline
\end{tabular}

Hasil pemeriksaan bobot jenis yang dapat dilihat pada tabel V, diketahui bahwa pada formula I dan II memiliki bobot jenis 1,03, sedangkan pada formula III didapat hasil yaitu 1,0. Hal ini menunjukkan bahwa formula I dan formula II memenuhi Standar Nasional Indonesia untuk sediaan shampoo yaitu minimal 1,02, Sedangkan formula III tidak memenuhi Standar Nasional Indonesia. Bobot jenis dipengaruhi oleh kompenen yang ada didalam sediaan tersebut. Semakin banyak komponen yang ada maka fraksi berat akan semakin tinggi. Sehingga bobot jenis juga akan semakin tinggi, viskositas berbanding lurus dengan bobot jenis, sehingga semakin tinggi bobot jenis semakin meningkat viskositas (Martin, dkk., 1993). Tetapi hal ini tidak terlihat pada penelitian ini.

Tabel VI. Hasil evaluasi viskositas sediaan shampoo cair ekstrak etanol daun alamanda

\begin{tabular}{ccccc}
\hline \multirow{2}{*}{ Formula } & \multicolumn{3}{c}{ Viskositas (dPa's) } & \multirow{2}{*}{$\begin{array}{c}\text { Rata-rata } \\
\text { bobot jenis }\end{array}$} \\
\cline { 2 - 4 } & Replikasi I & Replikasi II & Replikasi III & 0,43 \\
I & 0,5 & 0,4 & 0,4 & 0,96 \\
II & 0,9 & 1 & 1 & 1,5 \\
III & 1,5 & 1,5 & 1,5 & \\
\hline
\end{tabular}

Pengukuran viskositas bertujuan untuk mengetahui hubungan antara peningkatan konsentrasi carbopol dengan viskositas. Pada tabel VI diketahui viskositas pada formula I $0,43 \mathrm{dPa}$ 's, pada formula II $0,96 \mathrm{dPa}$ 's, dan formula III 1,5 dPa's. dari tabel VI terlihat bahwa semakin meningkat konsentrasi carbopol semakin meningkat pula viskositas shampoo. Hal ini dimana sesuai dengan fungsi carbopol yaitu sebagai pengental. Carbopol 940 yang digunakan pada sediaan shampoo ini dapat menaikan viskositas sediaan karena dapat mengembang dalam air sehingga membentuk suatu system gel yang kaku (Felicyta, 2010).

\section{KESIMPULAN}

Dari penelitian yang dilakukan dapat disimpulkan bahwa Hasil dari evaluasi organpleptis didapatkan shampoo ekstrak etanol daun alamanda berbau khas alamanda, berwarna hijau dan berbentuk cair. Hasil pengukuran pH didapatkan formula I dan II 4,2 dan formula III 6,8. Pada pengukuran tinggi busa didapatkan formula I tinggi busanya $6,1 \mathrm{~cm}$, formula II tinggi busanya $4,5 \mathrm{~cm}$, dan formula III tinggi busanya $4 \mathrm{~cm}$. pengukuran bobot jenis didapatkan formula I dan II adalah 1,03 dan formula III adalah 1. Pada pengukuran viskositas didapatkan s formula I 0,43 $\mathrm{dPa}$ 's, formula II $0,96 \mathrm{dPa}$ 's, dan formula III 1,5 dPa's. Berdasarkan hasil evaluasi diketahui bahwa sediaan shampoo ini masih layak untuk digunakan. 


\section{DAFTAR PUSTAKA}

Allen L. V., 2002, The Art science And technology of Pharmaceutical Compounding, American Pharmaceutical Association, Washington DC., 308-310

Ansel C. H,. 2005. Pengantar Bentuk Sediaan Farmasi. Edisi ke IV. Universitas Indonesia Press. Jakarta. 291-297

Arundhina, E, 2014, Aktivitas ekstrak etanol daun alamanda (Allamanda catharica L.)sebagai anti jamur terhadap Candida albicans DAN Pityrosporum ovale secara in vitro. Skripsi. Universitas Atmajaya Yogyakarta Fakultas Teknobiologi Program Studi Biologi, Yogyakarta. Di unduh pada tanggal 24 Oktober 2015. 70-71; 76-77; 92-93

Barel A. O., Paye M., dan Maibach H. I., 2009, Handbook of Cosmetic Science and Technology, $3^{\text {rd }}$ edition, Informa healthCare USA, Inc., New York, 462, 771, 777

Corcoran F., dan Akona K., 1997, The pH of Hair Shampoos: A Topical High School Experiment, Journal of Chemical Education, 54

Departemen Kesehatan Republik Indonesia. Formularium Kosmetika Indonesia. Jakarta: Direktorat Jenderal Pengawasan Obat dan Makanan; 1985. hal. 71-7, 284-99.

Faizatun, Kartiningsih dan Liliyana, 2008, Formulasi Sediaan Sampo Ekstrak Etanol Bunga Chamomile dengan Hidroksi Propil Metil Lelulosa Sebagai Pengental, Jurnal Kefarmasian Indonesia. 6: 15-22

Felicyta K. G., 2010, Pengaruh Peningkatan Konsentrasi Carbopol 940 Sebagai Bahan Pengental Terhadap Viskositas Dan Ketahanan Busa Sediaan Shampoo. Skripsi. Fakultas Farmasi Universitas Sanata Dharma Yogyakarta. Diunduh pada tanggal 3 Desember 2015. 12-13

Mahataranti, N., Astuti, Y. I., dan Asriningdhiani, B., 2012. Formulasi Shampo Antiketombe Ekstrak Seledri (Apium graveolens L.) dan Aktivitasnya Terhadap Jamur Pityrosporum Ovale. PHARMACY. 9: 128-139.

Martin A, Swarbick J, Cammarata A., 1993. Farmasi Fisik. Edisi III. Diterjemahkan oleh Yoshita. Univeristas Indonesia Press, Jakarta. 922-943,1077- 1103.

Michael dan Ash Irene, 1977. A Formulary Of Cosmetic Preparation. Chemical Publishing Co. New York. 222-233. 